\title{
Evaluation of Physical Aspects of Classroom Environment in Terms of the Humanistic Approach: A Comprehensive Theoretical Framework
}

\author{
Moatasim A. Barri \\ Correspondence: Moatasim A. Barri, Department of Curriculum and Teaching, Faculty of Education, Taibah University, \\ Medina, Saudi Arabia. Email: prof.barri@gmail.com
}

Received: August 18, 2020

doi:10.11114/jets.v8i11.4974
Accepted: September 15, $2020 \quad$ Online Published: September 16, 2020

URL: https://doi.org/10.11114/jets.v8i11.4974

\begin{abstract}
Building a school is an easy task, but keeping its physical facilities in a good condition is a real challenge. The literature indicates that the physical classroom environment has a critical role in the learning process. To optimize that role, the physical aspects being considered should be relevant to the human needs. This study was conducted to evaluate the physical aspects of classroom environment, which are related to students' needs. Data on 860 students from public high schools in Medina, Saudi Arabia, were collected using a paper-based closed-ended questionnaire. Multiple procedures were used for instrument validation, data screening, and data analysis. Findings from the study confirmed the validity of the proposed model for evaluating the physical environment. In addition, the findings suggest that the classroom environment needs improvement in the area of temperature, air quality, acoustics, class size, space, and cleanliness. Finally, implications for practice and future directions for research are discussed.
\end{abstract}

Keywords: student needs, comfort, well-being, safety, connection, self-worth, growth, furniture, space, lighting, temperature, air quality, cleanliness, color, layout, class size, ownership, acoustics, whiteboard, Saudi Arabia

\section{Introduction}

Students spend a majority of their time in the classroom during the school day, so an ideal classroom is needed for the best learning to occur. The classroom is a room in school where a class of students is taught. This room should be designed and furnished in a way that suits students' needs, interests, and aspirations. On the basis of the humanistic approach (Maslow, 1943), students are considered human beings with basic needs for comfort, well-being, safety, connection, self-worth, and growth. These needs have to be fulfilled, so students can engage in the learning activities and enjoy the classroom atmosphere. If students' needs are not being met, students are unlikely to engage in learning and, as a consequence, have difficulty to achieve the intended learning outcomes.

The classroom environment is defined as a learning space involving physical, emotional, and social aspects (Harris, 2018), which help both teachers and students perform their tasks efficiently. The social aspect focuses on students' interaction with their peers, teachers, and the environment, while the emotional aspect focuses on students' feelings toward the classroom environment. The physical aspect refers to the tangible or concrete things in the classroom surrounding, which can be observed by students' senses such as touch, sight, smell, hearing, and taste. Such tangible things may include furniture, temperature, lighting, air quality, color, space, design, class size, sound, safety, and cleanliness. Most research has been conducted on the influence of physical environment on students in the light of performance (Barrett, Davies, Zhang, \& Barrett, 2015a), impression (Weinstein \& Woolfolk, 1981), distraction and privacy (Ahrentzen \& Evans, 1984), and behavior (Loughlin, 1977). Little research has been written about the evaluation of the physical environment that corresponds to students' needs.

To evaluate means to judge the value or worth of something based on a set of criteria. The literature shows that the evaluation of a physical learning environment can lead to the improvement of instruction, greater growth in student learning, and greater support from the school district (Bennett, 1984). Thus, school facilities need to be evaluated from time to time in order to determine what works and what does not work. Evaluation focusing on the classroom environment is also needed to determine what is suitable and what is unsuitable for students and teachers. As students play an important role in the educational process, they tend to have an important influence on the evaluation of classroom environment. Therefore, more emphasis was placed on students' perceptions in the current study.

The classroom environment is considered an important topic for educational research since both learning and teaching 
process take place there. As the classroom environment becomes the main part of the educational process, its evaluation becomes particularly important for determining the worth or value of such a learning setting. It is also important to evaluate the physical aspects relating to students' needs to ensure an effective and efficient classroom environment and a community of committed students. The attempt was made, in the current study, to take advantage of students' perspectives in order to evaluate the physical aspects of the classroom environment which are relevant to students' needs.

\section{Research Framework}

\subsection{Humanistic Approach}

Humanism expands its roots in psychology (Ormrod, 2008) and focuses its attention on a human being as a whole (Huitt, 2009), particularly on human growth and development over the lifespan (Erikson,1950; Kohlberg, 1958; Piaget, 1952; Vygotsky, 1997). Humanists believe that human beings have abilities for determining truth and falsity (Edwords, 2008) and possess capacities for solving their own problems by reasonable and positive ways (Kurtz, 2000). Humanistic notions have an inclination to be grounded in philosophy than in research. However, some of these notions shed light on basic human needs (Hull, 1943; Maslow, 1943; Rogers, 1946).

\subsection{Students' Needs in the Classroom Environment}

Based on the theory of human needs (Maslow, 1943), the physical aspects of classroom environment should respond to students' needs in terms of the following:

1) Comfort: Students have a need to feel comfortable in their classroom.

2) Well-being: Students have a need to be healthy and well in their classroom.

3) Safety. Students have a need to feel safe and secure in their classroom.

4) Connection: Students have a need to make positive relationships with teachers and other students.

5) Self-worth: Students have a need to attain self-esteem and esteem from others.

6) Growth: Students have a need to reach their full potential through optimum experiences.

If students' needs are not being met, they are unlikely to reach the intended learning outcomes. Therefore, this paper considers the physical aspects of classroom environment that are relevant to the students' needs.

\subsection{Physical Aspects of Classroom Environment}

\subsubsection{Furniture}

A classroom with well-designed furniture can create a learning space that focuses on students and fosters a variety of learning activities, such as modeling, demonstrations, role plays, discussions, brainstorming, and problem solving (Barrett et al., 2015b) that prepare them to deal with real-world problems. Furniture such as desks and chairs should be chosen based on the following criteria:

1) Comfort: Desks and chairs should be comfortable for long periods and provide each student with enough space to work (Barrett et al., 2015b).

2) Mobility: Desks and chairs should be easy to move around the classroom, allowing students to see their teacher and break into small work groups (Harvey \& Kenyon, 2013).

3) Ergonomics: Desks and chairs should be ergonomic to students' ages and sizes in order to give the right sitting to the body (Castellucci, Arezes, \& Viviani, 2010; Panagiotopoulou, Christoulas, Papanckolaou, \& Mandroukas, 2004).

4) Durability: Desks and chairs should be made from durable materials in order to be stable during usage, resistant to repetitive usage and abuse from students, and able to give the same level of quality over a long period of time (Adewole \& Olorunnisola, 2010).

\subsubsection{Space}

The literature on space is concerned with the following query: How much space do students need to be comfortable in their learning environment? The magnitude of adequate space per student depends simply on the number of students within a given area (Tanner, 2009). Even though there are no criteria for building classrooms to specific dimensions, many schools over the world follow dimensions that are related to the institution of a positive learning environment. For schools in Saudi Arabia, a typical classroom has an area of 48 square meters, with a length of 8 meters and a width of 6 meters. It is supposed to hold 30 students as a maximum and allow an area of 1.6 square meters per student. However, the class size does matter because the overcrowded schools cause a reduction in the magnitude of space per student. The classroom environment should support flexibility to the extent which meet students' needs through any changing pedagogy (Barrett et al., 2015b). An arrangement of furniture should be also done in a way that allows students freedom 
of movement in their learning environment (Jindal-Snape et al., 2013) and supports action-based learning activities (Davies, 2011). Recent research shows that the availability of space is important for students to promote their creativity in a variety of learning activities (Davies et al., 2013; Jeffrey, 2006).

\subsubsection{Lighting}

Lighting is considered an essential component in a human life. Yet, the quality of lighting varies in terms of many conditions as follows: lighting color, illumination, artificial lighting, natural lighting, adequacy of lighting, presence of lighting control and so on. This leads to an important query of which lighting conditions optimize classroom environment in schools. Prior research on lighting variables of illumination and color temperature shows a positive impact on student performance (Keis, Helbig, Streb, \& Hille, 2014; Mott, Robinson, Walden, Burnette, \& Rutherford, 2012). A study conducted by Ott (1976) demonstrated a dramatic improvement in student behavior due to the usage of cool white lighting in the classroom. Research on lighting evaluation highlights significant differences between two types of artificial lighting, light-emitting diode (LED) and florescent light, in terms of comfort, attraction, cutting edge, stimulation, efficiency, and coziness. The LED was perceived better than the florescent in all variables, with the exception of coziness (Castilla, Llinares, Bisegna, \& Blanca-Giménez, 2018). The literature reveals the important role of natural lighting in human health (Boyce, 2010), productivity (Leslie, 2003), energy consumption (Drosou, Brembilla, Mardaljevic, \& Haines, 2016), and student performance (Heschong \& Knecht 2002; Heschong, Wright, \& Okura, 2002; Tanner, 2008). Despite the positive effects the natural lighting presents, the excessive exposure to it can introduce undesirable consequences such as solar heat (Benya, 2001) and visual discomfort (Ibañez et al., 2017). Evidence demonstrates inadequacy of lighting in the classroom, which can undermine student learning (Cheryan, Ziegler, Plaut, \& Meltzoff, 2014). Therefore, there is a need for the use of techniques that allow a better distribution of lighting (Ibañez, Zafra, \& Sacht, 2017). In spite of adequacy of lighting in the classroom, it was also found to cause discomfort for students due to light glare on some essential components of classroom furniture, such as desks and whiteboards (Winterbottom \& Wilkins, 2009). An emphasis was also placed on the presence of lighting control panel inside the classroom because of its positive effect on student engagement and mood during the school day (Morrow \& Kanakri, 2018).

\subsubsection{Temperature}

Students cannot stay focused in either hot or cold environment (Dunn \& Dunn, 1978), so the temperature should be set at an appropriate degree. The literature shows that the exposure to appropriate temperatures tends to have positive effects on individuals in term of school performance (Wargocki, Porras-Salazar, \& Contreras-Espinoza, 2019), thermal comfort and sensation (Aghniaey et al., 2019; Tham \& Willem, 2010), and mental alertness (Tham \& Willem, 2010). Prior research highlights the importance of temperature control in classrooms as an important factor for the learning process and recommends that the temperature control be functional and accessible to teachers (Barrett et al., 2015b).

\subsubsection{Air Quality}

One of the most humanistic aspects of classroom environment is to provide students with fresh air. Ventilation is a process of moving fresh air to or stale air from an enclosed area. The literature shows three types of ventilation: (a) natural ventilation that depends on winds, (b) mechanical ventilation that uses fans installed on walls, and (c) hybrid (mixed-mode) ventilation that relies on both natural and mechanical forces (Atkinson et al., 2009). Research on indoor air quality shows a lack of ventilation in many school classrooms (Johnson, Lynch, Floyd, Wang, \& Bartels, 2018). A couple of significant associations were shown between poor ventilation and increased illness absence (Mendell et al., 2013), reduced students' performance (Bakó-Biró, Clements-Croome, Kochhar, Awbi, \& Williams, 2012; Choi, Guerin, Kim, Brigham, \& Bauer, 2014), and risk of respiratory disorder (Choo, Jalaludin, Hamedon, \& Adam, 2015). All public schools in Saudi Arabia depend totally on natural ventilation, such as winds, to drive outdoor air through built openings such as windows and doors.

\subsubsection{Cleanliness}

Cleanliness refers to the state of being free of dirt, trash, and waste. It is considered one of the most important aspects of health and wellness. An environment that includes fresh air, purified water, and clean land is considered essential for human existence. Therefore, schools need to be clean in order to keep illness away from the classroom environment and keep students continuously in attendance. The clean setting can play an influential role in maintaining school attendance which can keep students' learning moving forward and, as a consequence, help them attain success on achievement tests.

\subsubsection{Color}

Design components within the classroom such as color tend to have effects on learners in terms of behavior (Read, Sugawara, \& Brandt, 1999), attention (Duyan \& Ünver, 2016), performance (Barrett et al., 2015a), and mood and well-being (Kuller, Mikellides, \& Janssens, 2009). Based on color psychology, walls of a light paint color give a feeling 
of happiness and warmth to a room, while dark colors give a feeling of depression (Institute of Inter-American Affairs, 1953). In addition, a ceiling of a white paint color improves classroom lighting and learners' eyesight (Institute of Inter-American Affairs, 1953).

\subsubsection{Safety}

Safety is defined as the condition of being secured from danger, injury, loss, or any undesirable effect. Safety was considered as a basic need in the theory of human needs (Maslow, 1943). People have a need to feel safe and secure in their environment. For students, feeling safe at school is associated with their attendance and academic performance (Arum, 2003). However, feelings of unsafety in school might cause an increase in student absenteeism, which in turn affects their performance negatively on assessments. For the current study, the term safety refers to the protection of students from physical components in school, which might cause injury to them. Therefore, classroom environment should be safe enough for students to be protected from the following: security issues (e.g., vandalism, bullying, theft) (Homrighaus, Davies, \& Bernardo, 2012), electrical hazards (Frumkin, Geller, Rubin \& Nodvin, 2006), fire (Homrighaus et al., 2012), falling down due to flooring conditions (Senda, 2015), falling from high places (Senda, 2015), nondurable furnishings (Adewole \& Olorunnisola, 2010), dangerous things (Frumkin et al., 2006; Richards-Babb, Bishoff, Carver, Fisher, \& Robertson-Honecker, 2010), and risky creatures (Frumkin et al., 2006).

\subsubsection{Layout}

Classroom layout refers to how students are seated in a given classroom. It is important for teachers to be acquainted with the seating arrangements, so they can make a good decision on an arrangement which best suits the instructional needs of their students. The classroom layout should be used as an approach to foster the interaction between teachers and students (Hastings \& Schweiso, 1995) and the interaction among students during the learning process (Rosenfield, Lambert, \& Black, 1985; van den Berg, Segers, \& Cillessen, 2012). There are several kinds of seating arrangements that allow students to perform a variety of learning activities such as the individual work using the row-and-column layout (Wannarka \& Ruhl, 2008), asking questions using the semicircle layout (Marx, Furher, \& Hartig, 2000), and student-based discussion using the cluster layout (Rosenfield et al., 1985).

\subsubsection{Class Size}

Class size refers to the number of students being taught by an individual teacher in a given classroom. Tanner (2009) highlights the importance of the number of students within a given space. The literature shows that smaller classes are associated with an increase in teacher-student interaction (Blatchford, Moriarty, Edmonds, \& Martin, 2002; Blatchford, Bassett, \& Brown, 2011), student engagement (Blatchford et al., 2011), and student performance (Francis \& Barnett, 2019). However, overcrowded classrooms can make difficulties for teachers in teaching and management (Blatchford \& Russell, 2019) and tend to have low academic achievement (Koc \& Celik, 2015).

\subsubsection{Ownership}

Research on psychology indicates that ownership of a place or object has an influence on the formation of one's identity and a sense of self-worth (Maxwell \& Chmielewski, 2008). Self-worth is a feeling of being worthy of respect and esteem. It was considered as a basic need in the theory of human needs (Maslow, 1943). The literature on classroom ownership indicates that personalized elements such as lockers, drawers, hooks, desks, and chairs can promote students' feelings of ownership, which in turn, encourages them to take responsibility for their learning (DeVries \& Zan, 1994). It is also argued that displaying students' works around the classroom can enhance their feelings of ownership and encourage them to get more involved in the learning process (Ulrich, 2004).

\subsubsection{Acoustics}

Acoustics refers to the control of sound within an enclosed area. Classrooms should be noiseless, so desirable sounds can be produced and received. This can be achieved by reducing noise within the indoor atmosphere in both classroom and school and the outdoor atmosphere, specifically, in the area around the school (Barrett et al., 2015b). For classrooms to be noiseless, the following conditions should be fulfilled: (a) the school should be located away from busy zones such as traffic, factories, and shops; (b) the classroom should be placed away from busy areas such as playground, toilets, and reception area; (c) the classroom should be free of noise sources such as noisy air conditioners, chairs and desks with no rubber feet, broken doors and windows, and uncarpeted floor; and (d) the students should be seated in an arrangement that allows students to be close enough to their teacher.

\subsubsection{Whiteboard}

A range of criteria were found to be important for the whiteboard to enhance better learning. The whiteboard should be placed in a position (Che Ahmad, Yahaya, Abdullah, Noh, \& Adnan, 2015) that offers comfortable viewing for all students and lots of room for teachers to write on. Based on the literature, whiteboards come in a variety of sizes, types, 
and costs. The recommendation for choosing the correct board size (Che Ahmad et al., 2015) depends on the kind of subject being taught and the kind of projector being used in the classroom. The literature shows that the recommended whiteboard size should have a minimum length of $3 \mathrm{~m}$ and a minimum height of $1.5 \mathrm{~m}$. This will accommodate projection from multiple kinds of projectors and teaching subjects from different disciplines. The recommendation for the best whiteboard (Che Ahmad et al., 2015) depends on the type of material used to make its surface. Based on the literature, the best board is the one that cleans easily, reduces glare, resists stains and ghosting, and stays white and bright forever. The whiteboard as a learning resource should be clean before using it, so the contents written on it will be visible to all students in the classroom (Pike, 2004).

\section{Methods}

\subsection{Settings}

The current study was conducted at public high schools from the Medina School District in Saudi Arabia. This school district was conveniently selected due to accessibility and proximity to the author and data collectors. Each public high school involved in the study has the following characteristics:

1) Is financed by government budget.

2) Is designed and built under the supervision of Ministry of Education.

3) Accepts students who reside in the school district.

4) Provides students with high quality of education that aims at building lifelong skills such as real-world problem solving, critical thinking, and self-directed learning.

5) Implements a school curriculum that meets the general education foundations.

6) Has certified teachers who have abilities to give high quality of instruction.

7) Has one principal who is in charge for school administration.

8) Has at least one vice-principal who is second in charge of the school after the principal.

9) Has at least one laboratory technician who prepares materials used during experiments.

10) Has at least one administrative assistant who is responsible for clerical work in the school's office.

11) Has one counselor who helps students cope with a variety of issues.

12) Has a crew who is responsible for all aspects of cleaning.

School infrastructure becomes a major factor for students to get high quality of education (Lackney, 1994) and to gain better outcomes (Fisher, 2001) in schools. Based on data collected using an observation method, each intended high school environment in Saudi Arabia included the following facilities: principal's room, vice-principals' rooms, counselor's room, teachers' rooms, classrooms, laboratories for science, art, and computer, library, canteen, restrooms, spacious lobby, storage, playing field, and sport room. All these facilities are displayed in Figure 1, Figure 2, and Figure 3 as a sample layout.

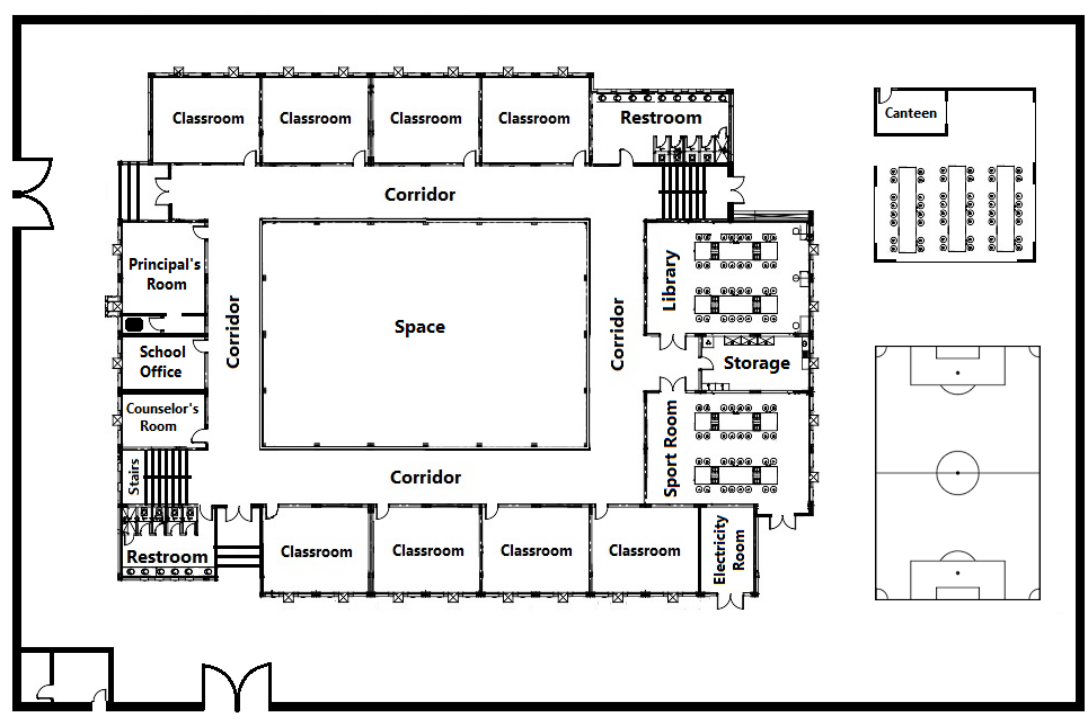

Figure 1. Ground floor plan of school 


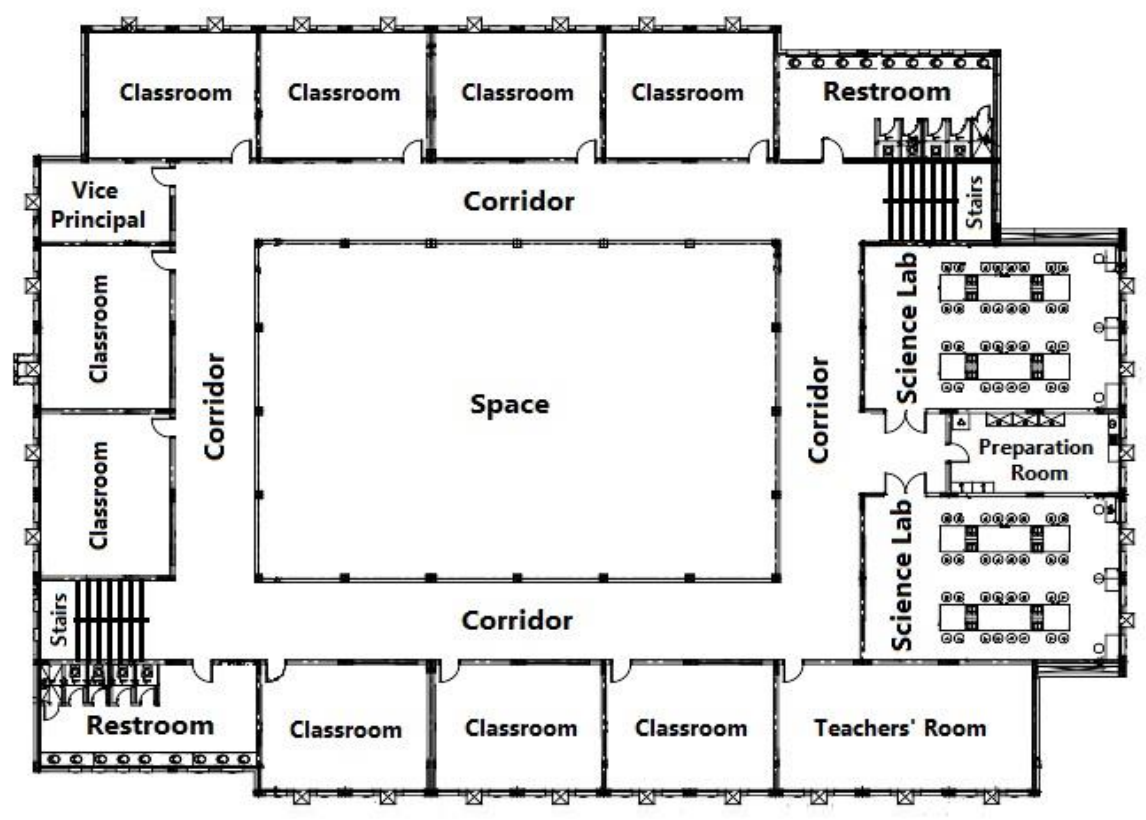

Figure 2. First floor plan of school

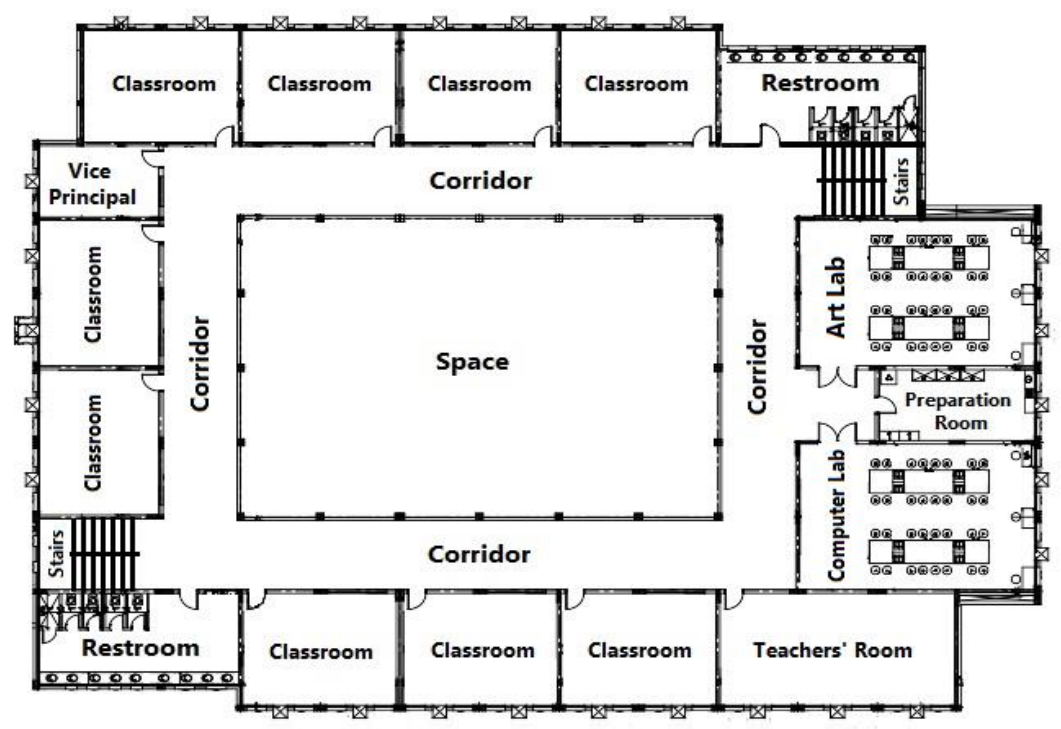

Figure 3. Second floor plan of school

For classrooms, prior research highlights the importance of classroom design on the academic progress of students in schools (Barrett et al., 2015b). Figure 4 and figure 5 display the most common classroom arrangements used in Saudi Arabian schools and used by the schools in the present study. Both arrangements are suitable for all class sizes. The arrangement shown below in Figure 4 is called the paired-column configuration, also known as the coupled or twinned-column configuration. This arrangement supports pair and group work. It revolves around both student-based discussion and teacher-based instruction. But the arrangement shown below in Figure 5 supports teacher-centric instruction, individual learning style, and test taking. 


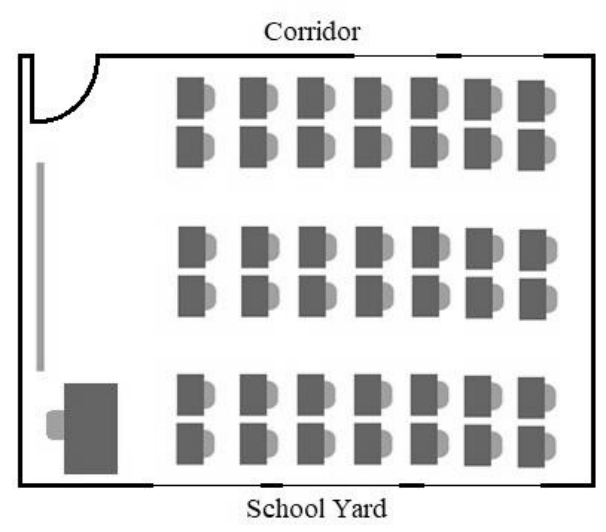

Figure 4. Coupled-column layout

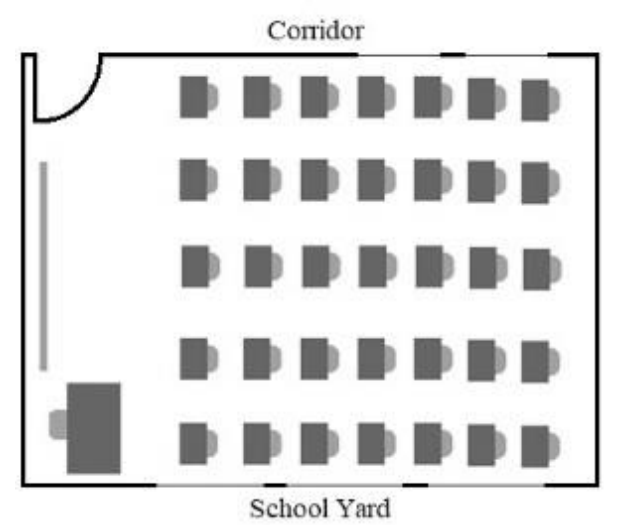

Figure 5. Single-column layout

\subsection{Participants}

The target population of this study was male students in grades 10 through 12 who attend all public schools in the Medina School District. There were 43 public high schools involved in the study. A group of 20 students was randomly selected from each school, forming a sample of 860 participants. A pencil-and-paper questionnaire was delivered to each student and all of them completed it.

\subsection{Procedures}

This study was conducted during Spring 2018. A group of university students, who took an elective course by the author, were assigned as data collectors in the study. They were initially asked via an online learning platform for their participation in the study by completing a consent form. They were fully informed of three parts of the study: (a) the purpose of the study, (b) the requirements of participation, and (c) voluntary participation. A list of school names and addresses was officially obtained from the Medina School District. Each data collector picked one public high school from the list in terms of accessibility and proximity. Written informed consents were obtained from all school principals for the fulfillment of conducting human subject research. The questionnaire was piloted with a small group of classroom students and slight corrections were made. A final draft of the questionnaire was delivered and collected manually. Participants were initially informed of important points relating to their participation in the current study as follows: (a) the purpose of the questionnaire, (b) voluntary participation, (c) privacy of participation, and (d) the requirements of participation.

\subsection{Instruments}

The current study utilized a quantitative approach to evaluate the physical aspects of classroom environment in terms of a humanistic approach. Due to contextual and cultural differences, schools across countries are going to be variant. Hoy and Miskel (1987) revealed that situations in schools are not static and the nature of each school depends on these dynamic situations. Accordingly, the physical aspects of the learning environment are changing from place to place and from time to time. Therefore, a comprehensive theoretical evaluation model was developed to serve the major goal of this study. A pencil-and-paper questionnaire was delivered to classroom students to collect data for this study. The 
questionnaire consisted of 52 statements split unevenly into fourteen dimensions: ownership of objects, quality of desks, quality of chairs, quality of whiteboard, space, layout, class size, lighting, temperature, paint color, ventilation, safety, acoustics and cleanliness. The statements used to measure each dimension are listed below in Table 1. The students were asked to read each statement carefully and then choose a response from a four-level Likert scale as follows: (1) strongly disagree, (2) disagree, (3) agree, and (4) strongly agree. Each response option represents an interval type of measurement. Having many response options within each statement is a way to enhance variability (DeVellis, 2003), which would, in turn, generate more reliable results.

Table 1. Research instrument items

\begin{tabular}{|c|c|}
\hline No. & Items \\
\hline & D1: Ownership (2 items) \\
\hline & The classroom offers me furnishings to.... \\
\hline 1 & keep my school materials neat and tidy. \\
\hline \multirow[t]{3}{*}{2} & perform my learning tasks (reading, writing, drawing). \\
\hline & D2: Desk (3 items) \\
\hline & My desk is .... \\
\hline 3 & of the suitable height. \\
\hline 4 & sturdy (not easily broken). \\
\hline \multirow[t]{3}{*}{5} & easy to be moved around. \\
\hline & D3: Chair (3 items) \\
\hline & My chair is .... \\
\hline 6 & of the suitable height. \\
\hline 7 & sturdy (not easily broken). \\
\hline \multirow[t]{3}{*}{8} & easy to be moved around. \\
\hline & D4: Whiteboard (4 items) \\
\hline & The whiteboard in my classroom is .... \\
\hline 9 & of the appropriate size. \\
\hline 10 & in the suitable place. \\
\hline 11 & easy to clean. \\
\hline \multirow[t]{3}{*}{12} & clear and bright. (free of anything that dims) \\
\hline & D5: Space (4 items) \\
\hline & The space in my classroom .... \\
\hline 13 & is adequate for the number of students. \\
\hline 14 & allows me flexibility to move around. \\
\hline 15 & allows me to perform a variety of learning activities. \\
\hline \multirow[t]{3}{*}{16} & allows me to perform action-based activities. \\
\hline & D6: Layout (3 items) \\
\hline & The seating arrangement in my classroom .... \\
\hline 17 & makes me interact with my teachers. \\
\hline 18 & makes me interact with my classmates. \\
\hline 19 & fits a variety of classroom activities. \\
\hline & D7: Class size (4 items) \\
\hline
\end{tabular}

The number of students in my classroom ....

20 fits the area of classroom. 


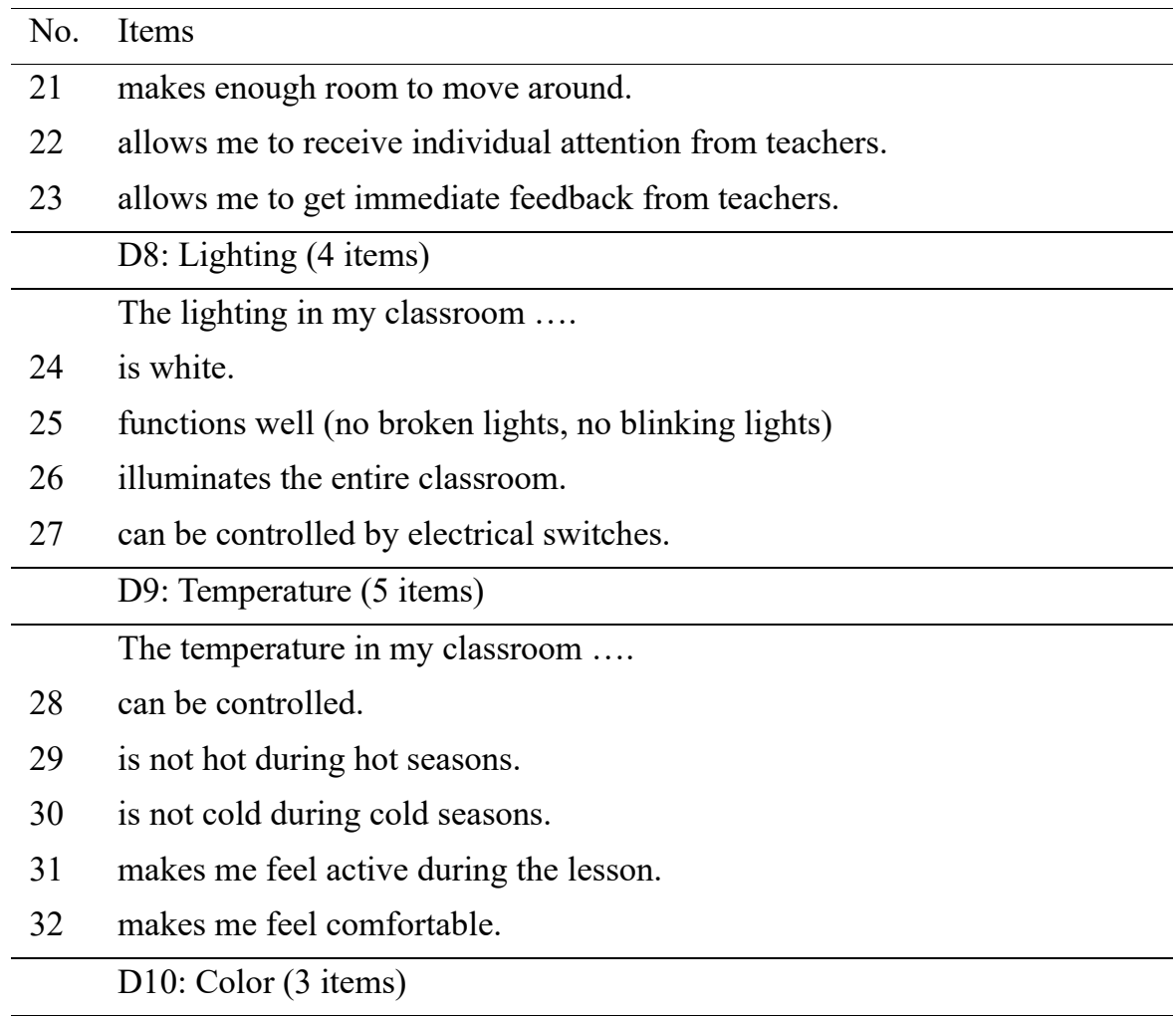

The color in my classroom ....

33 is light for ceiling and walls.

34 is bright for furnishings (floor, chair, desk, blinds).

35 makes me feel comfortable.

D11: Air quality (2 item)

Air quality in my classroom is appropriate due to ....

36 adequate built openings (windows, doors).

37 odorless atmosphere.

D12: Acoustics (2 items)

My teachers' speech is clear since ....

38 the classroom is free of noise sources. (noisy ACs, noisy ceiling fans, chairs and desks with no rubber feet, broken windows and doors)

39 the classroom is situated away from busy areas. (playground, toilets, reception office).

\begin{tabular}{|c|c|}
\hline & D13: Cleanliness (5 items) \\
\hline & My classroom has .... \\
\hline 40 & clean floor. (free of dirt and trashes) \\
\hline 41 & clean walls. (free of dirt and scribbles) \\
\hline 42 & clean ceiling. (free of dust and dirt) \\
\hline 43 & $\begin{array}{l}\text { clean fixtures. (fixed articles such as lockers, hooks, windows, doors, } \\
\text { lights) }\end{array}$ \\
\hline 44 & clean furniture. (movable articles such as chairs, desks) \\
\hline & D14: Safety (8 items) \\
\hline
\end{tabular}

My classroom is safe due to .... 


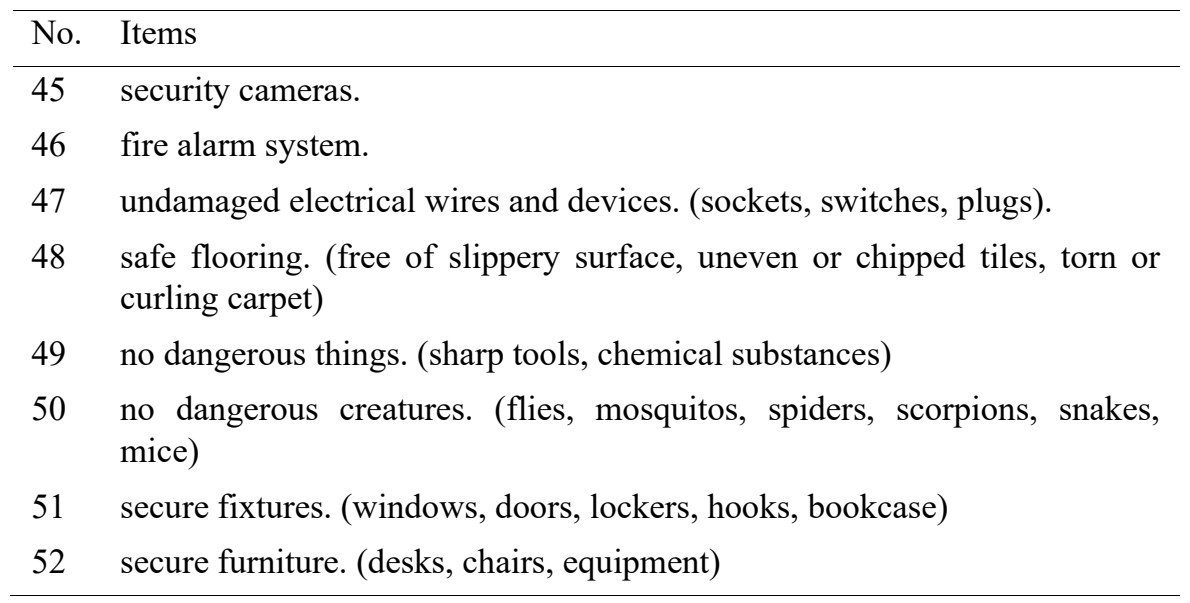

\subsection{Analysis of Instrument Validity}

\subsubsection{Analysis of Instrument Content Validity}

Content validity refers to the extent to which the dimensions of the research instrument are representative of a given construct and the items measuring an intended dimension are relevant to that dimension (Haynes et al., 1995). To develop the research instrument, the dimensions and their related criteria were drawn from the English-based literature that focuses on the physical classroom environment (see Table 2). The pilot study was conducted through three stages in order to address critical issues relating to the development, translation, and administration of the research instrument. The first stage involved in-depth discussions with experienced lecturers from the field of education. These discussions dealt with the following issues: (a) how each dimension can be related to the given construct being measured, (b) how each criterion can be relevant to the targeted dimension, and (c) how each item meets the corresponding criterion. The research instrument was modified according to the suggestions obtained from the lecturers.

The second stage of the pilot study addressed issues resulting from translating the research instrument from English to Arabic. The research instrument was originally developed in English since the literature review was performed on English sources. The instrument was translated to Arabic since it was intended to be applied to subjects from Arabic background. The translation process must receive critical attention since the poor-translated instrument might lead to low validity and reliability, which in turn result in irrelevant findings (Carlson, 2000). Any research instrument is translated from one language to another must be subjected to further pilot analysis, so the validity and reliability issues could be addressed (Griffee, 2001). Therefore, the procedure of back translation from Arabic to English was performed by an experienced translator, who had a good background in English and Arabic languages, to achieve conceptual equivalence. The content across the two English versions was compared and found to be conceptually the same.

In the third stage of the pilot study, the research instrument was piloted with a group of students who were similar to the study population. This stage was performed to address issues relating to the initial administration of the research instrument. Such issues included time spent to complete the research instrument, some vague instructions included in the cover letter, difficulty in the responding process, and ambiguities of some items. All issues suggested by students were resolved and the research instrument was revised accordingly. 
Table 2. Literature relevant to each dimension of the research instrument

\begin{tabular}{|c|c|c|c|c|}
\hline Dimension & Item & Criterion & Dominant Need & Relevant Literature \\
\hline \multirow{2}{*}{ Ownership } & 1 & Personalized objects & \multirow{2}{*}{ Self-worth } & \multirow{2}{*}{$\begin{array}{l}\text { (Barrett et al., 2015b; DeVries \& } \\
\text { Zan, 1994) }\end{array}$} \\
\hline & 2 & Personalized place & & \\
\hline \multirow{3}{*}{ Desk } & 3 & Ergonomics & \multirow{3}{*}{$\begin{array}{l}\text { Comfort } \\
\text { Safety } \\
\text { Well-being }\end{array}$} & \multirow{3}{*}{$\begin{array}{l}\text { (Adewole \& Olorunnisola, 2010; } \\
\text { Castellucci et al., 2010; Harvey \& } \\
\text { Kenyon, 2013) }\end{array}$} \\
\hline & 4 & Durability & & \\
\hline & 5 & Mobility & & \\
\hline \multirow{3}{*}{ Chair } & 6 & Ergonomics & Comfort & \multirow{3}{*}{$\begin{array}{l}\text { (Adewole \& Olorunnisola, 2010; } \\
\text { Castellucci et al., 2010; Harvey \& } \\
\text { Kenyon, 2013) }\end{array}$} \\
\hline & 7 & Durability & Safety & \\
\hline & 8 & Mobility & Well-being & \\
\hline \multirow{4}{*}{ Whiteboard } & 9 & Size & \multirow{4}{*}{ Growth } & \multirow{4}{*}{$\begin{array}{l}\text { (Che Ahmad et al., 2015; Pike, } \\
\text { 2004) }\end{array}$} \\
\hline & 10 & Position & & \\
\hline & 11 & Erasability & & \\
\hline & 12 & Visibility & & \\
\hline \multirow{4}{*}{ Space } & 13 & Adequacy & \multirow{2}{*}{ Comfort } & \multirow{4}{*}{$\begin{array}{l}\text { (Davies, 2011; Davies et al., 2013; } \\
\text { Jeffrey, 2006; Jindal-Snape et al., } \\
\text { 2013; Tanner, 2009) }\end{array}$} \\
\hline & 14 & Movability & & \\
\hline & 15 & Multiple utilizations & \multirow{2}{*}{ Growth } & \\
\hline & 16 & Action-based utilization & & \\
\hline \multirow{3}{*}{ Layout } & 17 & Student-student interaction & \multirow{2}{*}{ Connection } & \multirow{3}{*}{$\begin{array}{l}\text { (Hastings \& Schweiso, 1995; Marx } \\
\text { et al., 2000; Rosenfield et al., 1985; } \\
\text { van den Berg et al., 2012; } \\
\text { Wannarka \& Ruhl, 2008) }\end{array}$} \\
\hline & 18 & Student-teacher interaction & & \\
\hline & 19 & Student-environment interaction & Growth & \\
\hline \multirow{4}{*}{ Class size } & 20 & Suitability & \multirow{2}{*}{ Comfort } & (Blatchford et al., 2002; Mueller, \\
\hline & 21 & Enough space & & Chase, \& Walden, 1988; Tanner, \\
\hline & 22 & Individual attention & & \\
\hline & 23 & Immediate feedback & Growth & \\
\hline & 24 & White color & & (Cheryan et al., 2014; Drabble, \\
\hline I ighting & 25 & Functionality & Growth & 2016; Morrow \& Kanakri, 2018; \\
\hline Lighting & 26 & Adequacy & Growth & Ott, 1976) \\
\hline & 27 & Controllabiliy & & \\
\hline & 28 & Controllabiliy & & (Aghniaey et al., 2019; Barrett et \\
\hline & 29 & Air conditioning & & al., 2015b; Dunn \& Dunn, 1978; \\
\hline Temperature & 30 & Air heating & Comfort & Tham \& Willem, 2010) \\
\hline & 31 & Activeness & & \\
\hline & 32 & Feeling of comfort & & \\
\hline & 33 & Light ceiling and walls & & Inter-American \\
\hline Color & 34 & Bright furnishings & Comfort & Affairs, 1953; Kuller et al., 2009) \\
\hline & 35 & Feeling of comfort & & \\
\hline Air guality & 36 & Enough built openings & W/ll haing & (Cho thmod at 2015 ) \\
\hline Air quality & 37 & Odorless atmosphere & Well-being & (Che Ahmad et al., 2015) \\
\hline Asoustis & 38 & Noiseless indoor atmosphere & & (Porrettet ol 2015h) \\
\hline Acoustic & 39 & Noiseless outdoor atmosphere & Growth & (Barrett et al., 2015b) \\
\hline & 40 & Clean floor & & (Bluyssen, Zhang, \\
\hline & 41 & Clean walls & & Overtoom, \& Ortiz-Sanchez, 2018) \\
\hline Cleanliness & 42 & Clean ceiling & Well-being & \\
\hline & 43 & Clean fixtures & & \\
\hline & 44 & Clean furniture & & \\
\hline & 45 & Security cameras & & (Adewole \& Olorunnisola, 2010; \\
\hline & 46 & Fire alarm system & & Frumkin et al., 2006; Homrighaus \\
\hline & 47 & Electrical safety & & et al., 2012; Richards-Babb et al., \\
\hline & 48 & Safe flooring & & 2010; Senda, 2015) \\
\hline Safety & 49 & No dangerous things & Safety & \\
\hline & 50 & No dangerous creatures & & \\
\hline & 51 & Secure fixtures & & \\
\hline & 52 & Secure furniture & & \\
\hline
\end{tabular}




\subsubsection{Analysis of Instrument Construct Validity}

Construct validity refers to the extent to which a research instrument measures what it is supposed to measure. Factor analysis is an analytic method used to determine the number of dimensions that underlie a number of items within a research instrument (Kerlinger, 1979). It is a technique used to determine dimensions and their related items within the research instrument (Kerlinger, 1978). To ensure the construct validity of the existing instrument, factor analysis was run through two stages: extraction and rotation of dimensions. In the first stage, the principal components procedure was performed to extract the possible dimensions lying under the research instrument. An eigenvalue greater than one was used as a reference point to identify the dimensions which should be considered for the rotation stage (Green $\&$ Salkind, 2005). In the second stage, the varimax rotation procedure was run to determine which items should be considered for each dimension. Based on well-supported recommendations regarding the sample size in factor analysis (Gorsuch, 1983; Guilford, 1954; Kline, 1979), a sample size of 850 was found to be suitable for conducting a credible factor analysis. The Kaiser-Meyer-Olkin (KMO) test of sampling adequacy and The Bartlett's (1951) test of sphericity were utilized to determine whether the study data are suitable for the factor analysis. To check if the KMO test value is appropriate, Kaiser's index of factorial simplicity (Kaiser, 1974) was utilized.

The KMO test of sampling adequacy was performed and a value of 0.88 was obtained at $p<.001$. Based on the Kaiser's index of factorial simplicity (1974), this KMO value falls within an acceptable range and indicates that the factor analysis will provide reliable results. The Bartlett's test of sphericity was performed and a Chi-Squared value of 7431.86 was obtained at $p<0.001$ and a degree of freedom of 1326. This suggests that the factor analysis was suitable for the study data. Principal components factor analysis was run to identify the dimensionality of the 52 items from the research instrument. Based on Table 3, the magnitudes of eigenvalues indicated that the initial hypothesis of unidimensionality was rejected and there were fourteen dimensions to rotate using a varimax rotation procedure. The rotation solution, as shown in Table 3, yielded fourteen interpretable dimensions with $64.81 \%$ of the cumulative variance.

\subsubsection{Analysis of Instrument Reliability}

Coefficient alpha $(\alpha)$ is a measure of internal consistency of a set of instrument items (Cronbach, 1951). Multiple coefficient alphas were computed to determine the reliability of fourteen sets of items within the research instrument. According to Nunnally's (1978) recommendation to the reliability of an instrument used in basic research, Cronbach's alphas were determined to be acceptable for all constructs of the instrument, ranging from 0.69 to 0.85 (see Table 3 ). 
Table 3. Results of principal components factor analysis with a Varimax rotation procedure and Cronbach's alpha values

\begin{tabular}{|c|c|c|c|c|c|c|c|c|c|c|c|c|c|c|c|c|c|}
\hline \multirow[b]{2}{*}{ Item } & \multicolumn{14}{|c|}{ Factor Loading } & \multirow{2}{*}{$\begin{array}{l}\text { Eigen- } \\
\text { value }\end{array}$} & \multirow{2}{*}{$\begin{array}{r}\text { Var. } \\
\%\end{array}$} & \multirow{2}{*}{$\alpha$} \\
\hline & 1 & 2 & 3 & 4 & 5 & 6 & 7 & 8 & 9 & 10 & 11 & 12 & 13 & 14 & & & \\
\hline Ownership & & & & & & & & & & & & & & & 1.14 & 2.20 & .78 \\
\hline Item1 & .000 & .058 & .013 & .053 & .034 & .102 & .234 & .146 & .099 & .348 & .131 & .633 & -.068 & .118 & & & \\
\hline Item2 & -.028 & .069 & .087 & -.027 & .008 & .094 & .067 & .113 & .222 & .125 & .049 & .756 & .028 & -.035 & & & \\
\hline Desk & & & & & & & & & & & & & & & 1.25 & 2.41 & .69 \\
\hline Item3 & .075 & .011 & .082 & .064 & .001 & .013 & -.009 & .118 & .028 & .750 & .069 & .195 & .096 & .155 & & & \\
\hline Item4 & .102 & .145 & .015 & .014 & -.023 & .107 & .250 & .109 & .185 & .624 & .061 & .054 & .059 & -.041 & & & \\
\hline Item5 & .109 & .091 & .178 & .076 & .096 & .063 & -.012 & .020 & .183 & .610 & .058 & .008 & .061 & -.086 & & & \\
\hline Chair & & & & & & & & & & & & & & & 1.35 & 2.59 & .70 \\
\hline Item6 & .172 & .055 & .151 & .124 & .256 & $\begin{array}{l}.040 \\
\end{array}$ & -.026 & .150 & .685 & .190 & $\begin{array}{l}-.014 \\
\end{array}$ & .078 & $\begin{array}{l}-.052 \\
\end{array}$ & .032 & & & \\
\hline Item7 & .011 & .210 & .084 & .000 & .015 & .323 & .219 & .105 & .470 & .111 & -.043 & .201 & -.011 & .079 & & & \\
\hline Item8 & .035 & -.006 & .076 & .156 & .056 & .033 & .086 & .057 & .753 & .088 & .090 & .202 & .030 & .073 & & & \\
\hline Whiteboard & & & & & & & & & & & & & & & 1.50 & 2.88 & .76 \\
\hline Item9 & .169 & .064 & .030 & .127 & .062 & .058 & .677 & .090 & -.005 & -.023 & .069 & .312 & .164 & $\begin{array}{l}.074 \\
\end{array}$ & & & \\
\hline Item 10 & .054 & .199 & -.012 & .027 & .130 & .146 & .693 & .109 & -.039 & .202 & .063 & .220 & .089 & -.080 & & & \\
\hline Item11 & .039 & .053 & .278 & .079 & .091 & .119 & .668 & .112 & .113 & .037 & .061 & -.129 & -.047 & .177 & & & \\
\hline Item 12 & .006 & .176 & .232 & .104 & -.003 & .117 & .675 & .145 & .187 & .013 & -.009 & -.016 & .001 & .297 & & & \\
\hline Space & & & & & & & & & & & & & & & 2.85 & 5.48 & .83 \\
\hline Item 13 & .140 & .057 & .695 & .077 & .224 & .043 & .165 & .055 & .122 & .014 & -.043 & .141 & -.015 & .190 & & & \\
\hline Item 14 & .172 & .117 & .734 & .149 & .162 & .063 & .151 & .064 & .179 & .056 & -.013 & .093 & -.007 & .114 & & & \\
\hline Item 15 & .133 & .026 & .727 & .193 & .139 & .011 & .096 & .160 & .034 & .028 & .200 & .007 & .093 & -.111 & & & \\
\hline Item 16 & .227 & -.004 & .623 & .157 & .224 & -.020 & .006 & .191 & .055 & .188 & .091 & -.119 & .004 & -.016 & & & \\
\hline Layout & & & & & & & & & & & & & & & 1.39 & 2.61 & .77 \\
\hline Item17 & .117 & .056 & .083 & .063 & .012 & .113 & .130 & .787 & .121 & .062 & .027 & .134 & .094 & .080 & & & \\
\hline Item 18 & .089 & .105 & .105 & .045 & .165 & .056 & .075 & .812 & .031 & .117 & .056 & .080 & -.014 & .069 & & & \\
\hline Item 19 & .087 & -.046 & .263 & .112 & .119 & .017 & .149 & .633 & -.013 & .226 & .121 & .012 & .104 & -.060 & & & \\
\hline $\begin{array}{l}\text { Class Size } \\
\end{array}$ & & & & & & & & & & & & & & & 1.81 & 3.47 & .81 \\
\hline Item20 & .097 & .091 & .415 & .065 & .664 & .069 & .088 & .132 & -.065 & .037 & .087 & .183 & .098 & .133 & & & \\
\hline Item 21 & .080 & .050 & .366 & .100 & .692 & .115 & .054 & .078 & .019 & .114 & .079 & .031 & .058 & .025 & & & \\
\hline Item 22 & .122 & .132 & .266 & .154 & .702 & .184 & .079 & .069 & .052 & .110 & .113 & -.002 & .079 & -.088 & & & \\
\hline Item 23 & .190 & -.021 & -.017 & .177 & .619 & .177 & .089 & .116 & .270 & -.056 & -.035 & -.118 & .026 & .181 & & & \\
\hline Lighting & & & & & & & & & & & & & & & 1.64 & 3.15 & .76 \\
\hline Item 24 & .006 & .195 & -.016 & .021 & .150 & .714 & .109 & .162 & .017 & -.036 & .139 & .116 & .072 & .117 & & & \\
\hline Item 25 & .150 & .087 & .025 & .149 & .148 & .708 & .090 & .086 & .156 & -.059 & .139 & .104 & .104 & .021 & & & \\
\hline Item 26 & .112 & .156 & .085 & .130 & .087 & .713 & .114 & -.032 & .017 & .142 & .186 & -.002 & .164 & .038 & & & \\
\hline Item 27 & -.083 & .170 & .046 & .206 & .139 & .395 & .328 & -.111 & .102 & .201 & .200 & -.168 & .070 & -.035 & & & \\
\hline Temperature & & & & & & & & & & & & & & & 2.33 & 4.49 & .81 \\
\hline Item28 & .241 & .014 & .083 & .571 & .315 & .052 & .123 & .069 & .148 & .029 & .054 & -.212 & .051 & .103 & & & \\
\hline Item 29 & .131 & .173 & .091 & .705 & .115 & .240 & .039 & .047 & .058 & -.027 & .101 & -.106 & .106 & -.017 & & & \\
\hline Item 30 & -.002 & .233 & .035 & .539 & .053 & -.019 & .059 & .252 & .167 & .056 & .023 & .025 & .244 & -.002 & & & \\
\hline Item31 & .047 & .132 & .192 & .798 & -.041 & .067 & .027 & .040 & .086 & .103 & .059 & .078 & -.041 & .039 & & & \\
\hline Item 32 & .128 & .164 & .155 & .747 & .170 & .066 & .120 & -.033 & -.046 & .071 & .083 & .148 & .040 & -.008 & & & \\
\hline Color & & & & & & & & & & & & & & & 1.20 & 2.30 & .70 \\
\hline Item33 & .085 & .024 & .047 & .236 & .132 & .290 & .072 & .097 & .031 & .100 & .646 & .168 & .029 & .129 & & & \\
\hline Item34 & .036 & .090 & .038 & .077 & .060 & .309 & .057 & .082 & -.002 & .005 & .681 & .270 & .169 & .073 & & & \\
\hline Item35 & .177 & .162 & .280 & .058 & .025 & .147 & .076 & .083 & .201 & .103 & .609 & -.250 & -.051 & .108 & & & \\
\hline Air Quality & & & & & & & & & & & & & & & 1.05 & 1.95 & .73 \\
\hline Item 36 & .065 & .145 & .068 & -.023 & .078 & .116 & .097 & .097 & -.006 & .128 & .135 & .055 & .153 & .795 & & & \\
\hline Item 37 & .197 & .037 & .165 & .294 & .238 & .042 & .158 & -.014 & .036 & .055 & .169 & -.051 & .187 & .407 & & & \\
\hline Acoustics & & & & & & & & & & & & & & & 1.10 & 2.10 & .85 \\
\hline Item38 & .048 & $\begin{array}{l}.088 \\
\end{array}$ & $\begin{array}{l}.003 \\
\end{array}$ & $\begin{array}{l}.098 \\
\end{array}$ & .152 & .108 & .072 & .083 & .052 & .013 & $\begin{array}{l}.024 \\
\end{array}$ & .026 & .820 & .172 & & & \\
\hline Item39 & .112 & .213 & .064 & .119 & .008 & .211 & .065 & .068 & .028 & .090 & .095 & -.017 & .760 & .037 & & & \\
\hline Cleanliness & & & & & & & & & & & & & & & 3.22 & 6.18 & .83 \\
\hline Item 40 & .096 & .709 & .003 & .098 & .296 & .178 & .134 & .112 & .080 & .063 & .001 & .119 & -.059 & .079 & & & \\
\hline Item 41 & .198 & .661 & .072 & .147 & -.027 & .225 & .037 & .056 & .182 & .124 & -.081 & -.015 & .261 & -.010 & & & \\
\hline Item 42 & .016 & .691 & .048 & .133 & -.045 & .176 & .101 & -.006 & -.016 & .103 & .126 & -.023 & .119 & -.071 & & & \\
\hline Item 43 & .212 & .642 & .056 & .162 & -.068 & .118 & .058 & -.063 & .032 & -.016 & .071 & .083 & .098 & .258 & & & \\
\hline Item44 & .261 & .567 & .084 & .214 & .185 & -.077 & .181 & .118 & .015 & $\begin{array}{l}-.022 \\
-\end{array}$ & .117 & .054 & .031 & .079 & & & \\
\hline Safety & & & & & & & & & & & & & & & 11.98 & 23.03 & .80 \\
\hline Item 45 & .446 & .321 & -.051 & .112 & .163 & -.123 & .154 & .138 & .295 & -.084 & .256 & -.107 & $\begin{array}{l}.080 \\
\end{array}$ & -.052 & & & \\
\hline Item 46 & .652 & .165 & -.117 & .044 & .189 & -.138 & .105 & .011 & .147 & .071 & .290 & -.109 & .031 & -.042 & & & \\
\hline Item 47 & .601 & .256 & -.049 & .062 & .124 & -.121 & .133 & -.017 & .149 & .017 & .197 & -.073 & .184 & -.069 & & & \\
\hline Item 48 & .567 & .141 & .155 & .022 & -.002 & .014 & .080 & -.005 & .013 & .031 & .088 & .269 & .171 & .164 & & & \\
\hline Item 49 & .681 & .231 & .138 & .043 & - - & .219 & .047 & .143 & .062 & .080 & .051 & .022 & -.009 & -.057 & & & \\
\hline Item50 & .729 & .162 & .196 & .127 & -.003 & .155 & -.035 & .081 & .023 & .058 & -.115 & -.026 & -.060 & .076 & & & \\
\hline Item51 & .777 & -.039 & .139 & .114 & .104 & .086 & -.034 & .109 & -.029 & .066 & .043 & .072 & .026 & .059 & & & \\
\hline Item52 & .697 & -.117 & .247 & .074 & .119 & .072 & .025 & .006 & -.069 & .120 & -.147 & -.091 & -.011 & .087 & & & \\
\hline
\end{tabular}

\section{Data Screening and Analysis}

Before the process of data analysis, the raw data collected from participants were accurate on the basis of reasonable means, standard deviations, maximum, and minimum values of each of the instrument statements. According to the number of participants for each statement, none of the participants had missing. With the use of a $\mathrm{z}>|3.3|, \mathrm{p}<.001$ criterion (Tabachnich \& Fidell, 2007), no univariate outliers among the cases were found. Means were used to describe students' perceptions of the physical classroom environment in terms of the following aspects: ownership, desk, chair, whiteboard, space, layout, class size, lighting, temperature, color, air quality, acoustics, cleanliness, and safety. In the current study, the mean $(\mathrm{M})$ has a range of values from 1 to 4 . The interpretation of such a value was based on the following criteria: $1 \leq \mathrm{M} \leq 2.5$ is indicated as unsuitable, while $2.5<\mathrm{M} \leq 4$ is indicated as suitable. A table was used to display means and standard deviations for each dimension. 


\section{Results}

Table 4 displays means and standard deviations for students' perceptions of the physical aspects of the classroom environment. The means of students' perceptions of the fourteen dimensions ranged from 2.27 to 3.02 . The ownership of classroom received the highest average score overall, while cleanliness was the lowest. There was general agreement among participants that the physical aspects of the classroom environment including ownership, whiteboard, layout, desk, lighting, safety, color, and chair were suitable for them. However, the results indicated unsuitable physical aspects, including temperature, sound, space, air quality, class size, and cleanliness.

Table 4. Means and standard deviations for students' perceptions of the physical aspects of classroom environment

\begin{tabular}{lcc}
\hline Physical Aspect & Mean & SD \\
\hline Ownership & 3.02 & 0.78 \\
Whiteboard & 2.92 & 0.68 \\
Layout & 2.87 & 0.74 \\
Desk & 2.86 & 0.56 \\
Lighting & 2.86 & 0.64 \\
Safety & 2.81 & 0.64 \\
Color & 2.78 & 0.69 \\
Chair & 2.76 & 0.59 \\
Temperature & $\mathbf{2 . 4 6}$ & $\mathbf{0 . 7 4}$ \\
Acoustics & $\mathbf{2 . 4 5}$ & $\mathbf{0 . 8 4}$ \\
Space & $\mathbf{2 . 4 2}$ & $\mathbf{0 . 7 9}$ \\
Air quality & $\mathbf{2 . 3 7}$ & $\mathbf{0 . 7 1}$ \\
Class size & $\mathbf{2 . 3 2}$ & $\mathbf{0 . 7 5}$ \\
Cleanliness & $\mathbf{2 . 2 7}$ & $\mathbf{0 . 7 9}$ \\
\hline
\end{tabular}

\section{Discussion}

The data collected in the current study demonstrates that students overall reported acceptable aspects of the physical classroom environment including: a sense of ownership, quality whiteboard, well-designed classroom, good lighting, comfortable furniture, acceptable level of safety, and suitable color. However, some physical aspects including space, class size, air quality, temperature, cleanliness, and acoustics were found to be disconcerting.

Students reported that space was limited in the classroom. The issue of space arises due to a variety of reasons including crowding, the small classroom, or unsuitable arrangement of desks and chairs. In the current study, neither the small area nor classroom design are attributed to the issue of limited space, but the high density of classroom occupants as reported by students. In Saudi Arabia, the official area of classroom in public schools is 48 square meters. If the educational policy allocates an area of 1.6 square meters per student, the classroom will have a maximum capacity of 30 students. Therefore, any classroom with a capacity greater than 30 students will be considered crowded and offer little space for students. For classroom design, the most common desk-chair arrangements used in the Saudi public schools are the coupled- and the single-column as shown in Figure 4 and Figure 5 respectively. Both classroom arrangements can accommodate a high density of students. So, the conclusion drawn from this discussion is that the only reason behind the lack of space in our classrooms is the high density of students. Students have a need for space to feel comfortable in classroom, so they can engage more actively in their learning activities. The possible solution for this issue is to reduce the number of students per class. This solution can be reached through a short term by renting residential buildings or a long term by building new schools.

For air quality, the results indicated that classroom ventilation needs to be improved. Poor indoor air quality can increase the health problems and the level of discomfort among students, which in turn negatively impact their academic performance. The literature shows that poor air quality can be caused by many reasons as follows: (a) poor ventilation, (b) old buildings resulting in excessive humidity, and (c) proximity to sources of air pollution such as factories and traffic areas. In Saudi Arabia, all public schools depend totally on natural ventilation, such as winds, to drive outdoor air through windows and doors. If the ventilation openings are insufficient or close most of the time due to outdoor noise, that might prevent air circulation, which in turn produces stale air. In addition, many public school buildings are occupied for a long period of time, with no or very little renovation. These old buildings are likely to 
create a higher-humidity atmosphere, which allows mold to grow. Both higher humidity and mold growth are considered bad conditions which contribute to poor air quality. For air pollution, most of public schools are located inside of residential areas. However, since this study was conducted in a busy big city, some public schools might face poor air quality resulting from vehicle exhaust emissions.

The findings of the current study indicate that students perceived moderate concerns regarding the classroom temperature. That would be an indication of discomfort and inactivity for students, which can have negative effects on their academic performance. The temperature concerns might arise due to a variety of reasons including lack of air heating, improper functioning of air conditioners, and lack of window blinds. In essence, the public schools in Medina, Saudi Arabia, are not equipped with air heating. That is because the cold period is short, and the temperature seldom reaches or drops below $0 \mathrm{C}^{\circ}$. In spite of the short winter, the public schools need to be equipped with air heating to keep the classroom temperature at a comfortable level for learning conditions. In addition, Medina has a desert climate where temperature becomes high during the day and low at night through the warm seasons. Therefore, public schools need to be equipped with air conditioning in order to create a comfortable environment for learning. Even though the public schools are furnished with air conditioners, not all of them function properly. Most of the air conditioners run for a long period of time, so they function either with noise or without perfect cooling. Furthermore, direct sun heat might be a reason for students' concerns towards the classroom temperature. For our classrooms that face the direct sunrays, the absence of window blinds can make the temperature reach the undesired level of comfort.

The students were concerned about the undesirable level of noise within the classroom environment since they had trouble hearing their teachers clearly. The literature shows that exposure to noise can have negative effects on human performance and productivity. Thus, the classroom environment should be noiseless, so desirable sounds can be heard, and student growth in learning can be enhanced. The unwanted level of noise, as reported by students, might be attributed to a variety of possible reasons. The classes in high schools across Medina, Saudi Arabia, are usually large in size, up to 50 students per class, so students might face some difficulties to hear their teachers clearly. Some classrooms, especially the ones in unofficial school buildings, might be in a shape which allows unsuitable arrangement of seating. The classroom may include some noise sources such as noisy air conditioners, chairs and desks with no rubber feet, or broken doors and windows. The classroom may be located close to busy areas such as playground, toilets, noisy corridor, or reception area.

Cleanliness appeared to be an issue in the public high schools across Medina, Saudi Arabia, since it received the lowest average score among the physical aspects being evaluated. A clean classroom is one of the most important factors that contribute to student's health and academic growth. However, the literature indicates that a dirty classroom environment can have negative effects on students in terms of health, school attendance, and academic performance. In essence, an absence of cleanliness in the classroom facilities is associated with a couple of reasons including students' carelessness of cleanliness and lack of cleaning crew. Most public high schools are in trouble to allocate funds for cleaning crew and supplies due to the low school budget. Since contracting with cleaning company costs a lot of money, school principals go to employ two men who work seven hours. However, school facilities are still not clean since the number of the hired men might not be enough to serve the entire school. Therefore, their cleaning is usually superficial, and their tasks are limited to removing trash, sweeping floors, and cleaning sanitary school facilities. For students' carelessness of cleanliness, cleaning in schools is a public task, so high school students must be aware that they have part in school cleaning tasks. Once students begin to take care of their school, major changes will occur. The school facilities will remain clean and purposeful destruction will reduce as well. Unfortunately, the students used to rely on those who clean and make up their learning environment for them.

\section{Implications}

The findings of the current study have implications for government departments and institutions as follows:

Class size. Public high schools must provide teachers with practical tips for handling large classes in the light of management, teaching, and evaluation; and look for possible solutions for class size reduction. The school district must support the intended schools with professional development that deals with large classes. The Ministry of Education must plan to build new schools or rent buildings and hire more teachers in order to reduce the number of students per class. Education programs must prepare pre-service teachers for how to deal with large classes in terms of curriculum, pedagogy, management, and technology.

Space. The findings suggest that students need ample space in the classroom. This can be achieved by following these tips: (a) teachers should organize the furniture to allow for easy movement across different areas of the classroom, (b) teachers should employ a simple seating arrangement that offers more flexibility for students, (c) school planners should design a classroom with a large area and a simple shape, either a rectangular or squarer shape, and (d) school planners should allocate a storage area adjacent to the classroom, which can release ample space for classroom occupants. 
Temperature. If there are classrooms facing east, public high schools must ensure that external shading devices or internal blinds are installed at windows in order to obstruct sun heat and glare. In addition, public high schools must consider the following conditions: (a) air conditioners are in a good condition, (b) air heaters are available in classrooms during the winter season, and (c) the temperature control is accessible to classroom occupants.

Sound. To improve the auditory quality of the classroom, public high schools must ensure the following conditions: (a) movable furniture, such as chairs and desks, must have rubber feet, (b) the floor should be furnished with carpet, (c) noisy devices, such as window air conditioners and ceiling fan, must be fixed or replaced, (d) broken windows or doors must be repaired, and (e) the walls should be furnished with materials that absorb sounds. Teachers should employ a seating arrangement that allows students to be closer to them. When planning a school, school designers must keep the location of classrooms away from busy places. They should also design classrooms in a rectangular shape instead of a square to allow multiple layouts for teachers.

Air quality. For a large class size, active ventilation is needed in a classroom. Therefore, teachers should avoid closing the built openings, such as windows or doors, in the permanent manner. Public high schools must ensure that air quality monitors are available in classrooms, so teachers can be aware of any issue in air quality. School designers should consider large windows, high ceiling, mechanical ventilation system, and air quality monitor in the classroom design. In addition, the natural ventilation openings, such as windows, should be placed at different levels and different sides of the classroom and must be accessible to classroom occupants.

Cleanliness. One of the most important factors that contribute to students' academic success is to provide them with a clean learning environment. Therefore, public high schools must keep its facilities clean, organized, and tidy. This can be achieved by contracting with a cleaning company or hiring adequate cleaning staff and educating students to take responsibility for their cleaning actions and to care for their school building.

\section{Conclusion}

The current study proposed a valid and reliable evaluation model to assess the physical aspects of the classroom environment, which are relevant to students' needs. Conclusions drawn from the study findings indicate that students' perceptions were in agreement with physical aspects including furniture, classroom design, lighting, color, and safety. However, the classroom environment was found to be in need of some improvement in the area of temperature, air quality, class size, space, acoustics, and cleanliness.

The comprehensive evaluation model proposed in this study can help educational leaders and change agents find answers for questions such as: how physical classroom environment can be improved, why students are reluctant to engage in the learning process, and what physical aspects should be considered in the evaluation process. The evaluation model can help decision makers recognize areas that need improvement and obtain an overall assessment of quality of the physical classroom environment. The model can provide school communities with important information about their physical classroom environment, so they can optimize what they already have.

Although the current study provides insights into the physical classroom environment which corresponds to students' needs, it has some limitations. Given the convenience sampling procedure utilized in this study, the sample was not representative of the entire population. This sort of sampling may cause the study to produce results which are not capable of generalization. The study also took place at one school district, so the results might not be generalized to other school districts across the country or beyond. In addition, the data were collected from the secondary school settings within the urban areas; therefore, generalization should be restricted to these ecological conditions. The study was conducted in a particular point in time, so care must be taken into consideration when any generalization is made in the future.

Even though the present study brings together some of the prominent research on the physical classroom environment, it highlights some directions for future research. Since teachers are closely associated with the classroom environment, spend the most time in it, have the most effect on it, and are the most affected by it; they should be involved in the evaluation. Therefore, further research is needed to develop an evaluation model which takes teachers' perceptions into consideration. The results of the current study are obtained from a closed-end questionnaire, so further research should use qualitative approaches (e.g., observation, interviews, or open-end questionnaire) for elaboration. 


\section{References}

Adewole, N. A., \& Olorunnisola, A. O. (2010). Characteristics of classroom chairs and desks in use in senior secondary schools in Ibadan. Journal of Emerging Trends in Engineering and Applied Sciences, 1(2), 140-144.

Aghniaey, S., Lawrence, T. M., Sharpton, T. N., Douglass, S. P., Oliver, T., \& Sutter, M. (2019). Thermal comfort evaluation in campus classrooms during room temperature adjustment corresponding to demand response. Building and Environment, 148, 488-497. https://doi.org/10.1016/j.buildenv.2018.11.013

Ahrentzen, S., \& Evans, G. W. (1984). Distraction, privacy, and classroom design. Environment and Behavior, 16(4), 437-454. https://doi.org/10.1177/0013916584164002

Arum, R. (2003). Judging school discipline: The crisis of moral authority. Cambridge, MA: Harvard University Press.

Atkinson, J., Chartier, Y., Pessoa-Silva, C. L., Jensen, P., Li, Y., \& Seto, W.-H. (2009). Natural ventilation for infection control in health-care settings. Geneva: World Health Organization. Available from: https://www.ncbi.nlm.nih.gov/books/NBK143277/

Bakó-Biró, Zs., Clements-Croome, D. J., Kochhar, N., Awbi, H. B., \& Williams, M.J. (2012). Ventilation rates in schools and pupils' performance. Building and Environment, 48, 215-223. https://doi.org/10.1016/j.buildenv.2011.08.018

Barrett, P., Davies, F., Zhang, Y., \& Barrett, L. (2015a). The impact of classroom design on pupils' learning: Final results of a holistic, multi- level analysis. Building and Environment, 89, 118-133. https://doi.org/10.1016/j.buildenv.2015.02.013

Barrett, P., Zhang, Y., Davies, F., \& Barrett, L. (2015b). Clever classrooms: Summary report of the HEAD project. Salford: University of Salford.

Bartlett, M. S. (1951). The effect of standardization on a Chi-square approximation in factor analysis. Biometrika, 38(3/4), 337-344. https://doi.org/10.1093/biomet/38.3-4.337

Bennett, D. B. (1984). Evaluating environmental education in schools: A practice guide for teachers. Unesco-UNEP International Environmental Education Programme.

Benya, J. R. (2001). Lighting for schools. Washington, DC: National Clearinghouse for Educational Facilities. Retrieved from http://www.ncef.org/pubs/lighting.pdf

Blatchford, P., \& Russell, A. (2019). Class size, grouping practices and classroom management. International Journal of Educational Research, 96, 154-163. https://doi.org/10.1016/j.ijer.2018.09.004

Blatchford, P., Bassett, P., \& Brown, P. (2011). Examining the effect of class size on classroom engagement and teacher-pupil interaction: Differences in relation to pupil prior attainment and primary vs. secondary schools. Learning and Instruction, 21(6), 715-730. https://doi.org/10.1016/j.learninstruc.2011.04.001

Blatchford, P., Moriarty, V., Edmonds, S., \& Martin, C. (2002). Relationships between class size and teaching: A multimethod analysis of English infant schools. American Educational Research Journal, 39(1), 101-132. https://doi.org/10.3102/00028312039001101

Bluyssen, P. M., Zhang, D., Kurvers, S., Overtoom, M., \& Ortiz-Sanchez, M. (2018). Self-reported health and comfort of school children in 54 classrooms of 21 Dutch school buildings. Building and Environment, 138, 106-123. https://doi.org/10.1016/j.buildenv.2018.04.032

Boyce, P. R. (2010). Review: The impact of light in buildings on human health. Indoor and Built Environment, 19(1), 8-20. https://doi.org/10.1177/1420326X09358028

Carlson, E. D. (2000). A case study in translation methodology using the Health-Promotion Lifestyle Profile II. Public Health Nursing, 17(1), 61-70. https://doi.org/10.1046/j.1525-1446.2000.00061.x

Castellucci, H. I., Arezes, P. M., \& Viviani, C. A. (2010). Mismatch between classroom furniture and anthropometric measures in Chilean schools. Applied Ergonomics, 41(4), 563-568. https://doi.org/10.1016/j.apergo.2009.12.001

Castilla, N., Llinares, C., Bisegna, F., \& Blanca-Giménez, V. (2018). Emotional evaluation of lighting in university classrooms: A preliminary study. Frontiers of Architectural Research, 7(4), 600-609. https://doi.org/10.1016/j.foar.2018.07.002

Che Ahmad, C. N., Yahaya, A., Abdullah, M. F., Noh, N. M., \& Adnan, M. (2015). An instrument to assess physical aspects of classroom environment in Malaysia. International Journal of Arts and Sciences, 8(2), 1-12.

Cheryan, S., Ziegler, S. A., Plaut, V. C., \& Meltzoff, A. N. (2014). Designing classrooms to maximize student 
achievement. Policy Insights from the Behavioral and Brain Sciences, 1(1), 4-12. https://doi.org/10.1177/2372732214548677

Choi, S., Guerin, D., Kim, H., Brigham, J., \& Bauer, T. (2014). Indoor environmental quality of classrooms and student outcomes: A path analysis approach. Journal of Learning Spaces, 2(2). Retrieved from http://libjournal.uncg.edu/jls/article/view/506

Choo, C. P., Jalaludin, J., Hamedon, T. R., \& Adam, N. M. (2015). Preschools' indoor air quality and respiratory health symptoms among preschoolers in Selangor. Procedia Environmental Sciences, 30, 303-308. https://doi.org/10.1016/j.proenv.2015.10.054

Cronbach, L. J. (1951). Coefficient alpha and the internal structure of tests. Psychometrika, 16(3), 297-334. https://doi.org/10.1007/BF02310555

Davies, D. (2011). Teaching science creatively. London: Routledge. https://doi.org/10.4324/9780203839980

Davies, D., Jindal-Snape, D., Collier, C., Digby, R., Hay, P., \& Howe, A. (2013). Creative learning environments in education: A systematic literature review. Thinking Skills and Creativity, 8, 80-91. https://doi.org/10.1016/j.tsc.2012.07.004

DeVellis, R. F. (2003). Scale development: Theory and applications. Thousand Oaks, CA: Sage Publications.

DeVries R., \& Zan, B. (1994). Moral classrooms, moral children: Creating a constructivist atmosphere in early education. New York, NY: Teachers' College Press.

Drabble, C. (2016). Supporting children with special educational needs and disability. London, UK: Bloomsbury.

Drosou, N., Brembilla, E., Mardaljevic, J., \& Haines, V. (2016). Reality bites: Measuring actual daylighting performance in classrooms, presented at 32nd International Conference on Passive and Low Energy Architecture, Los Angeles, 2016. Los Angeles, CA: PLEA.

Dunn, R., \& Dunn, K. (1978). Teaching students through their individual learning styles: A practical approach. Reston, VA: Reston.

Duyan, F., \& Ünver, R. (2016). A research on the effect of classroom wall colours on student's attention. ITU A|Z, 13(2), 73-78. https://doi.org/10.5505/itujfa.2016.57441

Edwords, F. (2008). What is humanism? Retrieved May 07, 2019, from https://americanhumanist.org/what-is-humanism/edwords-what-is-humanism/

Erikson, E. H. (1950). Childhood and society. New York, NY: W. W. Norton

Fisher, K. (2001). Building better outcomes: The impact of school infrastructure on student outcomes and behavior. Schooling Issues Digest.

Francis, J., \& Barnett, W. S. (2019). Relating preschool class size to classroom quality and student achievement. Early Childhood Research Quarterly, 49, 49-58. https://doi.org/10.1016/j.ecresq.2019.05.002

Frumkin, H., Geller, R. J., Rubin L., \& Nodvin, J. (2006). Safe and healthy school environments. New York, NY: Oxford University Press. https://doi.org/10.1093/acprof:oso/9780195179477.001.0001

Gorsuch, R. L. (1983). Factor analysis. Hillsdale, NJ: Erlbaum.

Green, S. B., \& Salkind, N.J. (2005). Using SPSS for Windows and Macintosh: Analyzing and understanding data. Upper Saddle River, New Jersey: Pearson Prentice Hall.

Griffee, D. T. (2001). Questionnaire translation and questionnaire validation: Are they the same? Paper presented at the Annual Meeting of the American Association for Applied Linguistics, St. Louis, MO, 24-27 February 2001.

Guilford, J. P. (1954). Psychometric methods. New York, NY: McGraw-Hill.

Harris, H. (2018). Addressing special educational needs and disability in the curriculum: geography. London: Routledge. https://doi.org/10.4324/9781315457772

Harvey, E. J., \& Kenyon, M. C. (2013). Classroom seating considerations for 21 st century students and faculty. Journal of Learning Spaces, 2(1). Retrieved from http://libjournal.uncg.edu/jls/article/view/578

Hastings, N., \& Schweiso, J. (1995). Tasks and tables: The effects of seating arrangements on task engagement in primary classrooms. Educational Research, 37(3), 279-291. https://doi.org/10.1080/0013188950370306

Haynes, S. N., Richard, D. C. S., \& Kubany, E. S. (1995). Content validity in psychological assessment: A functional approach to concepts and methods. Psychological Assessment, 7(3), 238-247. 
https://doi.org/10.1037/1040-3590.7.3.238

Heschong, L., \& Knecht, C. (2002). Daylighting makes a difference. Educational Facility Planner, 37(2), 5-14.

Heschong, L., Wright, R., \& Okura, S. (2002). Daylighting impacts on human performance in school. Journal of Illuminating Engineering Society, 31, 101-114. https://doi.org/10.1080/00994480.2002.10748396

Homrighaus, H. L., Davies, F. J., \& Bernardo, G. (2012). A primer on electronic security for schools, universities, and institutions. Argyle, TX: Aella Consulting Group.

Hoy, W., \& Miskel, C. (1987). Educational administration: Theory, research and practice. New York: McGraw-Hill Ltd.

Huitt, W. (2009). Humanism and open education. Retrieved May 04, 2019, from http://www.edpsycinteractive.org/topics/affect/humed.html

Hull, C. L. (1943). Principles of behavior: An introduction to behavior theory. New York, NY: Appleton-Century-Crofts.

Ibañez, C. A., Zafra, J. C. G., \& Sacht H. M. (2017). Natural and artificial lighting analysis in a classroom of technical drawing: Measurements and HDR images use. Procedia Engineering, 196, 964-971. https://doi.org/10.1016/j.proeng.2017.08.037

Institute of Inter-American Affairs. (1953). Teachers' handbook for use by teachers in rural elementary schools. Washington: Institute of Inter-American Affairs, Division of Education.

Jeffrey, B. (2006). Creative teaching and learning: Towards a common discourse and practice. Cambridge Journal of Education, 36(3), 399-414. https://doi.org/10.1080/03057640600866015

Jindal-Snape, D., Davies, D., Collier, C., Howe, A., Digby, R., \& Hay, P. (2013). The impact of creative learning environments on learners: A systematic literature review. Improving Schools, 16(1), 21-31. https://doi.org/10.1177/1365480213478461

Johnson, D. L., Lynch, R. A., Floyd, E. L., Wang, J., \& Bartels, J. N. (2018). Indoor air quality in classrooms: Environmental measures and effective ventilation rate modeling in urban elementary schools. Building and Environment, 136, 185-197. https://doi.org/10.1016/j.buildenv.2018.03.040

Kaiser, H. F. (1974). An index of factorial simplicity. Psychometrika, 39(1), 31-36. https://doi.org/10.1007/BF02291575

Keis, O., Helbig, H., Streb, J., \& Hille, K. (2014). Influence of blue-enriched classroom lighting on students' cognitive performance. Trends in Neuroscience and Education, 3(3-4), 86-92. https://doi.org/10.1016/j.tine.2014.09.001

Kerlinger, F.N. (1978). Foundations of behavioral research. New York, NY: McGrawHill.

Kerlinger, F.N. (1979). Behavioral research: A conceptual approach. Dallas, Texas: Holt, Rinehart and Winston.

Kline, P. (1979). Psychometrics and psychology. London: Academic Press

Koc, N., \& Celik, B. (2015). The impact of number of students per teacher on student achievement. Procedia - Social and Behavioral Sciences, 177, 65-70. https://doi.org/10.1016/j.sbspro.2015.02.335

Kohlberg, L. (1958). The development of modes of thinking and choices in years 10 to 16 (Doctoral Dissertation).

Kuller, R., Mikellides, B., \& Janssens, J. (2009). Color, arousal, and performance: A comparison of three experiments. Color Research and Application, 34(2), 141-152. https://doi.org/10.1002/col.20476

Kurtz, P. (2000). Humanist manifesto 2000: A call for a new planetary humanism. Amherst, NY: Prometheus Books.

Lackney, J. A. (1994). Educational facilities: The impact and role of the physical environment of the school on teaching, learning and educational outcomes. Milwaukee, WI, USA: Center for Architecture and Urban Planning Research, University of Wisconsin-Milwaukee.

Leslie, R. P. (2003). Capturing the daylight dividend in buildings: Why and how?. Building and Environment, 38(2), 381-385. https://doi.org/10.1016/S0360-1323(02)00118-X

Loughlin, C. E. (1977). Understanding the learning environment. The Elementary School Journal, 78(2), 125-131. https://doi.org/10.1086/461093

Marx, A., Furher, U., \& Hartig, T. (2000). Effects of classroom seating arrangements on children's question-asking. Learning Environment Research, 2, 249-263. https://doi.org/10.1023/A:1009901922191

Maslow, A. H. (1943). A theory of human motivation. Psychological Review, 50, 370-396. https://doi.org/10.1037/h0054346 
Maxwell, L., \& Chmielewski, E. (2008). Environmental personalization and elementary school children's self-esteem. Journal of Environmental Psychology, 28, 143-153. https://doi.org/10.1016/j.jenvp.2007.10.009

Mendell, M. J., Eliseeva, E. A., Davies, M. M., Spears, M., Lobscheid, A., Fisk, W. J., \& Apte, M. G. (2013). Association of classroom ventilation with reduced illness absence: A prospective study in California elementary schools. Indoor Air, 23(6), 515-528. https://doi.org/10.1111/ina.12042

Morrow, B. L., \& Kanakri, S. M. (2018). The impact of fluorescent and led lighting on students attitudes and behavior in the classroom. Advances in Pediatric Research, 5(15), 1-12. https://doi.org/10.24105/apr.2018.5.15

Mott, M. S., Robinson, D. H., Walden, A., Burnette, J., \& Rutherford, A. S. (2012). Illuminating the effects of dynamic lighting on student learning. SAGE Open, 2(2), 1-9. https://doi.org/10.1177/2158244012445585

Mueller, D. J., Chase, C. I., \& Walden, J. D. (1988). Effects of reduced class sizes in primary classes. Educational Leadership, 45(5), 48-50.

Nunnally, J. C. (1978). Psychometric theory. New York, NY: McGraw-Hill.

Ormrod, J. E. (2008). Human learning (5th ed.). Upper Saddle River, NJ: Pearson Prentice Hall.

Ott, J. N. (1976). Influence of fluorescent lights on hyperactivity and learning disabilities. Journal of Learning Disabilities, 9(7), 417-422. https://doi.org/10.1177/002221947600900704

Panagiotopoulou, G., Christoulas, K., Papanckolaou, A., \& Mandroukas, K. (2004). Classroom furniture dimensions and anthropometric measures in primary school. Applied Ergonomics, 35(2), 121-128. https://doi.org/10.1016/j.apergo.2003.11.002

Piaget, J. (1952). The origins of intelligence in children. New York, NY: International Universities Press. https://doi.org/10.1037/11494-000

Pike, M. A. (2004). Teaching secondary English. London: Paul Chapman Publishing.

Read, M. A., Sugawara, A. I., \& Brandt, J. A. (1999). Impact of space and color in the physical environment on preschool children's cooperative behavior. Environment and Behavior, 31(3), 413-428. https://doi.org/10.1177/00139169921972173

Richards-Babb, M., Bishoff, J., Carver, J. S., Fisher, K., \& Robertson-Honecker, J. (2010). Keeping it safe: Chemical safety in the high school laboratory. Journal of Chemical Health and Safety, 17(1), 6-14. https://doi.org/10.1016/j.jchas.2009.05.001

Rogers, C. R. (1946). Significant aspects of client-centered therapy. American Psychologist, 1(10), 415-422. https://doi.org/10.1037/h0060866

Rosenfield, P., Lambert, N. M., \& Black, A. (1985). Desk arrangement effects on pupil classroom behavior. Journal of Educational Psychology, 77(1), 101-108. https://doi.org/10.1037/0022-0663.77.1.101

Senda, M. (2015). Safety in public spaces for children's play and learning. IATSS Research, 38(2), 103-115. https://doi.org/10.1016/j.iatssr.2015.02.001

Tabachnich, B. G., \& Fidell, L. S. (2007). Using multivariate statistics. Boston, Massachusetts: Pearson Education.

Tanner, C. K. (2008). Explaining relationships among student outcomes and the school's physical environment. Journal of Advanced Academics, 19(3), 444-471. https://doi.org/10.4219/jaa-2008-812

Tanner, C. K. (2009). Minimum classroom size and number of students per classroom: Revised findings and conclusions. Retrieved September 21, 2019, from

https://www.scarsdaleschools.k12.ny.us/cms/lib/NY01001205/Centricity/Domain/1105/2014-11-19\%20Meeting\% 20of\%20Greenacres\%20Building\%20Committee\%20Meeting\%20Handout $\% 203 \% 20-\% 20$ Classroom $\% 20$ Size $\% 2$ 0Standards.pdf

Tham, K. W., \& Willem, H. C. (2010). Room air temperature affects occupants' physiology, perceptions and mental alertness. Building and Environment, 45(1), 40-44. https://doi.org/10.1016/j.buildenv.2009.04.002

Ulrich, C. (2004). A place of their own: Children and the physical environment. Human Ecology, 32(2), 11-14.

van den Berg, Y. H. M., Segers, E., \& Cillessen, A. H. N. (2012). Changing peer perceptions and victimization through classroom arrangements: A field experiment. Journal Abnormal Child Psychology, 40, 403-412. https://doi.org/10.1007/s10802-011-9567-6

Vygotsky, L. S. (1997). Educational psychology. Boca Raton, FL: St. Lucie Press.

Wannarka, R., \& Ruhl, K. (2008). Seating arrangements that promote positive academic and behavioral outcomes: A 
review of empirical research. Support for Learning, 23, 89-93. https://doi.org/10.1111/j.1467-9604.2008.00375.x

Wargocki, P., Porras-Salazar, J. A., \& Contreras-Espinoza, S. (2019). The relationship between classroom temperature and children's performance in school. Building and Environment, 157, $197-204$. https://doi.org/10.1016/j.buildenv.2019.04.046

Weinstein, C. S., \& Woolfolk, A. E. (1981). Classroom design and impression formation: A new area for research. Contemporary Educational Psychology, 6(4), 383-386. https://doi.org/10.1016/0361-476X(81)90020-5

Winterbottom, M., \& Wilkins, A. (2009). Lighting and discomfort in the classroom. Journal of Environmental Psychology, 29(1), 63-75. https://doi.org/10.1016/j.jenvp.2008.11.007

\section{Copyrights}

Copyright for this article is retained by the author(s), with first publication rights granted to the journal.

This is an open-access article distributed under the terms and conditions of the Creative Commons Attribution license which permits unrestricted use, distribution, and reproduction in any medium, provided the original work is properly cited. 